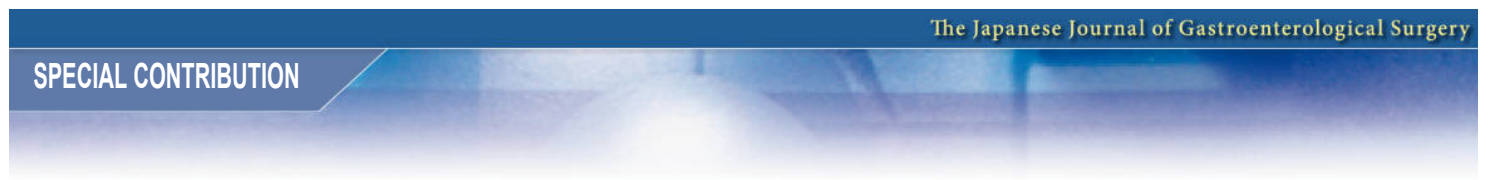

\title{
Congress Presentations and Duplicate Publication
}

\author{
Takako Kojima $^{1) 2)}$, Sae Nakano ${ }^{3)}$ and J. Patrick Barron ${ }^{4) 5) 6)}$ \\ 1) Associate Professor, Department of International Medical Communications, Tokyo Medical University \\ ${ }^{2)}$ Member, COPE \\ ${ }^{3)}$ Freelance Translator \\ 4) Emeritus Professor, Tokyo Medical University \\ ${ }^{5)}$ Council Member, COPE \\ 6) Adjunct Professor, Seoul National Bundang Hospital
}

The following case presented to the Committee of Publication Ethics (COPE) ${ }^{1)}$, discusses the issue of prior publication, specifically regarding recorded audio material from conferences. Before reading the content of this case, it is important to understand how the International Committee of Medical Journal Editors (ICMJE) views this issue. The ICMJE states that "prior publication can include release of information in the public domain. This policy applies whether presentations at conferences are made in person or via the Web or online". ${ }^{2)}$

Based on this, audiotapes from conferences would be considered prior publication although it will not prevent the author from being able to publish that as a full publication, therefore no need to consider the possible risk of duplicate publication. However, would the situation be different if the conference retained copyright of such materials?

Case number: $18-10^{3)} \quad$ Are copyrighted conference audiotapes considered "prior publication"?

\section{Case text (Anonymized)}

An editor received a query from an author: "Your guidelines are clear that presenting data at a society meeting does not preclude publication. But what if the society records the presentation, retains copyright of that recording, and posts it online? Is asking presenters to turn over copyright of a recording of data presented at a prepublication stage and disseminating the recording as they see fit crossing the "prior publication" line?"

Question(s) for the COPE Forum

- Are presentation audiotapes considered prior publication?

- If tapes are copyrighted, does that preclude publication?

\section{Advice:}

Copyright laws are there to protect publishers and they cover only the presentation of something and not the underlying research or data. In the case of audiotapes, the organization only owns the audio rights not the paper rights, so the editor should check the copyright that has previously been assigned. It is also possible that the audiotapes are behind a paywall for members only, so the distribution of the material might be very limited. There is a need, however, to seek legal advice in such cases and the editor should consult the legal department of the publisher if there is any question. Additionally, when a paper is presented, it is not generally presented in the same format as a scholarly paper submitted to a journal, so there might be significant differences between the audio and the written material, with the exception of the data presented. The main concern is duplicate publication; however, audiotapes are not generally considered primary sources for the purpose of reviews of the literature.

There is a similar situation with dissertations. Do poster presentations have the same copyright rules? Generally, previous presentations in the form of papers presented at a conference are allowed although there might be some text overlap with the abstract, which is usually all that is printed. In other situations, a published abstract in English might accompany an article written in another language, but with appropriate credits, a 
complete translation of that article might be appropriate for publication.

The parameters of prior publication are a journal decision. For example, journals can decide to publish papers arising out of a dissertation or an audit that has been circulated internally in an institution, but they should be transparent and disclose previous publication or copyright of any portion of the material. One view from the Forum was that copyright issues support paternalistic ideas of protecting people from something that has not been peer reviewed, and this might be an issue for certain disciplines. Another question journals might consider relates to their policies of issuing press releases. Some journals employ the Ingelfinger Rule and embargoes to preclude the spread of misinformation, particularly in research related to public health and safety.

\title{
Follow up:
}

The matter was resolved in the author's favor. The association changed its policy requiring presenters to have presentations taped and to hand over copyright.

\section{Resolution: Case Closed Year: 2018}

\author{
[日本語訳] \\ 事例番号：18-10＼cjkstart著作権で保護された学会の録音テープは，「事前掲載（prior publication）」とみなされる
} か?

\section{事例の内容（匿名）}

編集長は，ある著者から質問を受けた，「貴委員会のガイドラインには，学会で発表した内容はその後の出版を 不可能にするものではない」と明記されている．しかし学会がプレゼンテーション内容を録音し，その著作権を保 有し，それをオンライン上に掲載する場合はどうなるだろうか? 発表者に, 掲載前の段階で発表したデー夕の録音 の著作権を譲渡するよう要請し，録音内容を発信することは，「事前揭載」の一線を越えることにはならないのだ ろうか?

COPE フォーラムへの質問：

・プレゼンテーションを録音したテープは，事前掲載とみなされるか？

・テープが著作権で保護されている場合，掲載はできないのだろうか？

\section{COPE からの助言 :}

著作権法は出版社を保護するためにあり，それは，何らかの発表にのみ適用され，その基礎となる研究やデー夕 には適用されない，録音テープの場合，学会は録音に対する権利のみを有し，論文の権利は有さないので，編集者 は，譲渡された著作権が何だったのかをチェックするべきである．また，録音テープは学会会員のためだけの有料 コンテンツ内にある可能性があり，その場合，その配信は非常に限定的であるかもしれない. しかし，このような ケースでは法的な助言を求める必要があり，編集者は，疑問があれば出版社の法務部門に相談するべきである。さ らに，論文のプレゼンテーションは，一般的に，学術論文をジャーナルに投稿するのと同じフォーマットで行われ るわけではない，そのため，プレゼンテーションが録音されたものと実際の論文の間には，デー夕を除き，かなり の違いがある可能性がある，主な懸念事項としては重複掲載だが，録音テープは文献のレビューを目的とする際の 主要な情報源とはみなされないのが一般的である。

学位論文についても同じようなことが言える。ポスター発表には同様の著作権のルールが適用されるのだろう か? 一般的に, 学会で紙媒体にて発表された以前の発表は, 通常唯一印刷される抄録と内容の一部分が重複してい ても認められる。 また別のケースで，英語で揭載された抄録に他の言語で書かれた論文が付随している場合，適切 な説明があり，その論文の全文が翻訳されていれば，掲載するのが適切な場合もある.

事前掲載の条件は, ジャーナルが決定する．例えば，ジャーナルは，施設内で回覧されている学位論文または審 査中の論文の掲載を決めることができる。しかし，それには透明性が不可欠で，その論文のいかなる部分であれ， 以前掲載されたり著作権が譲渡されたりしている場合は，それらについて開示しなければならない。フォーラムで 述べられた一つの意見として，著作権問題は，読者をピアレビューされていないものから守るという父親的温情主 義的な考え方によるものであり，ある分野では問題になる可能性もある，というものがあった。もう一つジャーナ ルが考慮する可能性のある問題は，プレスリリースの方針に関連するものである．ジャーナルの中には，特に公共 の健康と安全に関係する研究について, 誤った情報の拡散を阻止するため, Ingelfinger Rule や出版の差し止めを採 用しているものもある.

\section{その後の経過 :}

本件は，著者の望む形で解決した，学会は発表者にプレゼンテーションの内容をテープに録音させ，その著作権 を譲渡することを要求するという方針を変更した。 
According to the Ingelfinger Rule, which owes its name to the editor of the New England Journal of Medicine (NEJM), who expressed it in 1969, although an earlier version of the same policy had been stated earlier by Samuel Goudsmit, editor of the Physical Review Letters, in 1960, material published elsewhere would not be considered for publication in the NEJM. The policy of the NEJM is very strictly enforced, and that journal will not consider for publication any material that has appeared in any form whatsoever.

Thus, presenting material at a conference, strictly speaking, would contravene the Ingelfinger Rule, but one must remember that this edict was promulgated in the era before electronic publishing, archiving, and data sharing. As a result of the latter, the modus operandi of scholarly publications have been, and will be further, changed. This was pointed out by Stevan Harnad in his perceptive manuscript. ${ }^{4)}$ In this, he points out that interoperable, widelydistributed, eprint archives can now be harvested and shared optimally electronically, significantly affecting journals' revenue streams. He reasons that journals will be forced to rely financially on their quality control and certification services, paid for by author/institutions on a per-paper basis. He concludes succinctly: "Ingelfinger over-ruled."

\section{[日本語訳]}

Ingelfinger Rule の名称は, それを 1969 年に表明した NEJM の編集長の名前に由来している. しかし, 同 じ方針は，それより早く1960 年に, Physical Review Letters の編集長であった Samuel Goudsmitにより表明 されている. NEJMではどこか他で掲載されたものについては掲載を考慮しない, とした。 この方針は非 常に厳格に施行され，NEJM は，どのような形式であれ他の媒体に掲載されたものは掲載対象とみなして いない.

したがって，厳密に言えば，学会で発表されるものは Ingelfinger Rule とは矛盾するだろう。しかし Ingelfinger Rule が電子媒体による掲載，文書保管，デー夕共有の時代が到来する前に公表されたものだと いうことを思い出さなければならない, その結果, 学術論文などの掲載方法は, 変わってきており, 今後 さらに変化するだろう。これについては, Stevan Harnad が彼の洞察力のある原稿の中で指摘している. 彼 によれば, 現在では, 相互に情報交換可能なフォーマットで配信されるデジタル原稿のアーカイブを, 最 も効率的に電子的に収集し，共有することができ，それはジャーナルの収入の動向に重大な影響を及ぼし ている. ジャーナルは，掲載する論文などの品質管理と科学的真実の保証サービスに注力し，財政的には 論文 1 本ごとに著者や所属施設から支払われる掲載料金に頼らざるをえなくなるだろうと論じている。そ して，彼は「Ingelfinger Rule は覆された」と簡潔に結論づけている.

\section{Closing Message}

As editors observing changes over the past decades in medical publishing and medical publishing ethics, which are in fact the raison d'être of COPE, we have noted that the situation has now changed to such an extent that the Follow-up conclusion reached by COPE concerning this instance is in fact something with which we can totally agree.

With increasing methods of disseminating information, careful understanding about issues such as prior publication, duplicate publication, and copyright become essential in protecting authors.

\section{References}

1) The Committee on Publication Ethics. http://publicationethics.org/ [Accessed January 20, 2019].

2) International Committee of Medical Journal Editors. Recommendations for the Conduct, Reporting, Editing, and Publication of Scholarly Work in Medical Journals [Internet]. Available from http://www.icmje.org/ [Accessed January 20, 2019].

3) The Committee on Publication Ethics. http://publicationethics.org/cases [Accessed January 20, 2019 ].

4) Harnad S. Ingelfinger Over-Ruled: The Role of the Web in the Future of Refereed Medical Journal Publishing. The Lancet Perspectives. 2000;256(December Supplement):s16. 